\title{
METAL OXIDES AS SOLUBLE NANO CATALYST ON BIODIESEL: A REVIEW
}

\author{
Setyo Pambudi*,1, Agus Triono ${ }^{1}$, Mochamad Asrofi ${ }^{1,4}$, Iid Mufaidah ${ }^{2}$, Yeni Variyana ${ }^{3}$, R. A. \\ Ilyas $^{5}$
}

\author{
${ }^{1}$ Department of Industrial Engineering, Banyuwangi Institute of Technology and Business \\ Muhammadiyah, Banyuwangi, Indonesia \\ ${ }^{2}$ Department of Agribusiness, Banyuwangi Institute of Technology and Business Muhammadiyah, \\ Banyuwangi, Indonesia \\ ${ }^{3}$ Department of Chemical Engineering, Banyuwangi Institute of Technology and Business \\ Muhammadiyah, Banyuwangi, Indonesia \\ ${ }^{4}$ Department of Mechanical Engineering, University of Jember, Jember, Indonesia \\ ${ }^{5}$ Center for Advanced Composite Materials, Universiti Teknologi Malaysia, Johor, Malaysia \\ *Corresponding author \\ Email: setyopmbd@gmail.com
}

\begin{abstract}
Nano particles of metal oxide developed as soluble nano additive in liquid fuels to improve fuel quality. One application of nano metal oxide particles is an additive to biodiesel. Biodiesel is an alternative fuel that can reduce dependence on fossil fuels. Pure biodiesel has a relatively lower calorific value compared to fossil fuels. Low calorific value results in increased brake specific fuel consumption. Moreover, biodiesel has a higher density and viscosity compared to fossil fuel. The content of carbon monoxide (CO), unburned hydrocarbons (HC) and nitrogen oxide (NOx) in exhaust gases with biodiesel is higher than fossil fuels. Metal oxide nanoparticles are added to biodiesel between 6 to $80 \mathrm{~nm}$ with concentrations about 50 to $500 \mathrm{ppm}$. Addition of metal oxide nanoparticles to biodiesel can improve brake thermal efficiency, reduce brake specific fuel consumption, carbon monoxide (CO), unburned hydrocarbons (HC), nitrogen oxide (NOx) and improve carbon dioxide $\left(\mathrm{CO}_{2}\right)$ emission due to the catalytic effect of metal oxide nanoparticles. Metal oxide acts as an oxidation catalyst thereby reduce the carbon combustion activation temperature and thus enhances hydrocarbon oxidation, promoting complete combustion. Nanoparticles that are often used in various studies are nickel (II) oxide (NiO), cerium (IV) oxide $\left(\mathrm{CeO}_{2}\right)$, titanium oxide $\left(\mathrm{TiO}_{2}\right)$, zinc oxide $(\mathrm{ZnO})$, aluminum oxide $\left(\mathrm{Al}_{2} \mathrm{O}_{3}\right)$, and silicon dioxide $\left(\mathrm{SiO}_{2}\right)$. This review paper describes the progress and development of nano metal oxide applications as additives for biodiesel, and the discussion in this paper is divided into 3 main topics, including the effects of nanoparticles on the properties of biodiesel, engine performance, and emission characteristics.
\end{abstract}

Keywords: nanoparticles; catalytic effect; biodiesel; engine performance; fuel consumption; exhaust gases

\section{Introduction}

The world's energy needs still depend on fossil fuels. Liquid fuel is one of the fuels that continues to increase in consumption. The world's consumption of liquid fuels is estimated to increase from 95 million barrels per day (b/d) in 2015 to 113 million b/d in 2040. Liquid fuel consumption is increasing in the industrial and transportation sectors (Energy, 2017). Bioenergy is promoted to reduce dependence on non-renewable (fossil) fuels and to reduce greenhouse gas emissions. Bioenergy is a non-fossil fuel produced from plants and animals (biological processes). Utilization of bio energy currently reaches $50 \mathrm{EJ} / \mathrm{year}$ or about $10 \%$ of global energy needs. The 
potential of major global bioenergy techniques by 2050 is estimated to reach $160-270 \mathrm{EJ} / \mathrm{year}$ (Haberl et al., 2010). One of the most widely developed of bioenergy currently is biodiesel.

Biodiesel is an environmentally friendly alternative fuel for ignition compression engines. Biodiesel has better properties than petrodiesel because it is made from renewable materials such as vegetable and animal oils, is non-toxic and biodegradable converted by soil and water borne organisms, and is free of sulfur and aromatics (Demirbas, 2005). Biodiesel or Fatty Acid Methyl Ester (FAME) can be made from various vegetables or animal oils (Fukuda et al., 2001; Van Gerpen, 2005). Triacylglycerides (TAG) or often called triglycerides are vegetable oils or animal oils used to produce biodiesel. In general, transesterification is a biodiesel production process. It is the reaction between triglycerides and alcohol in the presence of a catalyst to produce fatty acid alkyl esters. Glycerin is referred to as glycerol that is a by-product of transesterification, and methanol is the most commonly used alcohol (Hoekman \& Robbins, 2012).

The use of biodiesel in compression ignition engines can reduce smoke opacity but increase Brake Specific Fuel Consumption (BSFC) (Özener et al., 2014). The smaller calorific value of biodiesel compared to petrodiesel causes an increase in fuel consumption. Biodiesel requires more fuel consumption to get the same power output as petrodiesel (Rahman et al., 2013). In addition, the use of biodiesel also reduces Brake Thermal Efficiency (BTE). Unburned hydrocarbons (HC), Carbon Monoxide (CO) in biodiesel were found to be lower than petrodiesel (Chauhan et al., 2011). However, Nitrogen Oxide (NOx) contained in exhaust gas was significantly increased when using biodiesel compared to petrodiesel (Ashok et al., 2017; Dhar et al., 2012; How et al., 2018; Raheman \& Ghadge, 2007). Biodiesel has five main long carbon chains including, FAME: methyl palmitate (MP, $\mathrm{C}_{17} \mathrm{H}_{34} \mathrm{O}_{2}$ ) and methyl stearate (MS, $\mathrm{C}_{19} \mathrm{H}_{38} \mathrm{O}_{2}$ ) as saturated FAME, methyl oleate $\left(\mathrm{MO}, \mathrm{C}_{19} \mathrm{H}_{36} \mathrm{O}_{2}\right)$, methyl stearate $\left(\mathrm{MS}, \mathrm{C}_{19} \mathrm{H}_{38} \mathrm{O}_{2}\right)$ as saturated FAME, methyl oleate (MO, $\mathrm{C}_{19} \mathrm{H}_{36} \mathrm{O}_{2}$ ), methyl linoleate (ML, $\mathrm{C}_{19} \mathrm{H}_{34} \mathrm{O}_{2}$ ) and methyl linolenate (MLE, $\mathrm{C}_{17} \mathrm{H}_{32} \mathrm{O}_{2}$ ) as unsaturated FAME (Herbinet et al., 2008). Biodiesel contains bound oxygen thereby suppressing the formation of soot particles. The soot particles result in reduced radiant heat transfer thereby increasing the reaction temperature and increasing NOx formation (Varatharajan \& Cheralathan, 2012).

Catalytic combustion is widely used in various fields, especially in the use of efficient and low pollutant fossil fuels. Catalytic combustion can increase efficiency and reduce NOx pollutant emissions (Gong et al., 2018). Catalytic combustion is also often used in small-scale combustion. The catalyst can increase the flame stability limit. The fire is more stable even though it is in a very small space and far from the stoichiometric Air Fuel Ratio (AFR) (Wang et al., 2010; Wierzbicki et al., 2014). In internal combustion engines, it is impractical to add catalyst to the combustion chamber. To improve performance and to reduce internal combustion engine 
emissions, the catalyst is mixed directly in the liquid fuel. Catalyst is added in nano-sized liquid fuel. Nano-sized metal catalysts can dissolve and mix in liquid fuels. Catalysts in liquid fuels are often referred to as nano-additives (Wickham et al., 2006).

Nano metal oxide is often used to improve performance and to enhace biodiesel exhaust gases. From the background above, this paper aims to provide an overview of several things are the use of nano metal oxide as a soluble nano catalyst, the effects among soluble nano catalyst on biodiesel properties, soluble nano catalyst on biodiesel performance, and soluble nano catalyst on biodiesel exhaust gases. This paper is a narrative review by comparing several studies to find conclusions and match them with existing theories.

\section{Present state of the art: nano metal oxide}

Metal oxide belongs to an important group of engineered nanoparticles, besides being used in liquid metal additives, nano metal oxide is widely used in cosmetics and sunscreens, coatings and textiles that clean themselves. Other applications include its use as an air fuel and battery processing agent and newer car catalytic converters (Puzyn et al., 2011). Furthermore, ultrasound is used to mix biodiesel with nano metal oxide. Furthermore, ultrasound is used to mix biodiesel with nano metal oxide. Figure 1 shows a soluble nano catalyst mixed with biodiesel using an ultrasonicator.

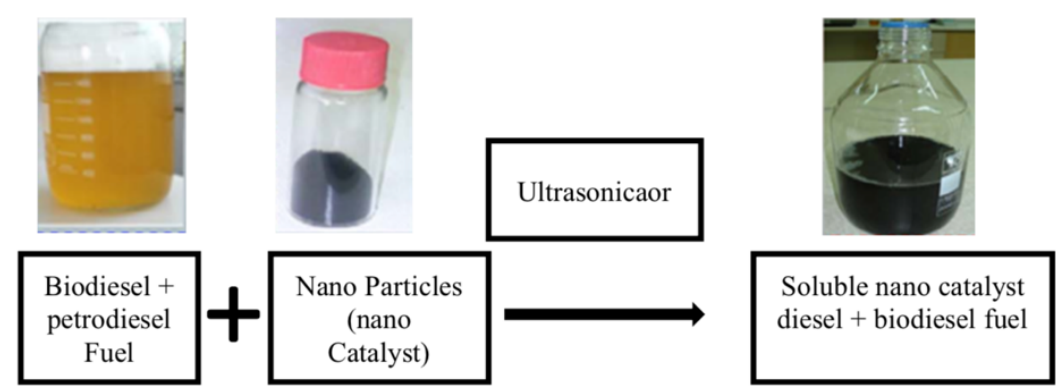

Figure 1. Soluble nanocatalyst mixed with using an ultrasonicator (Najafi, 2018)

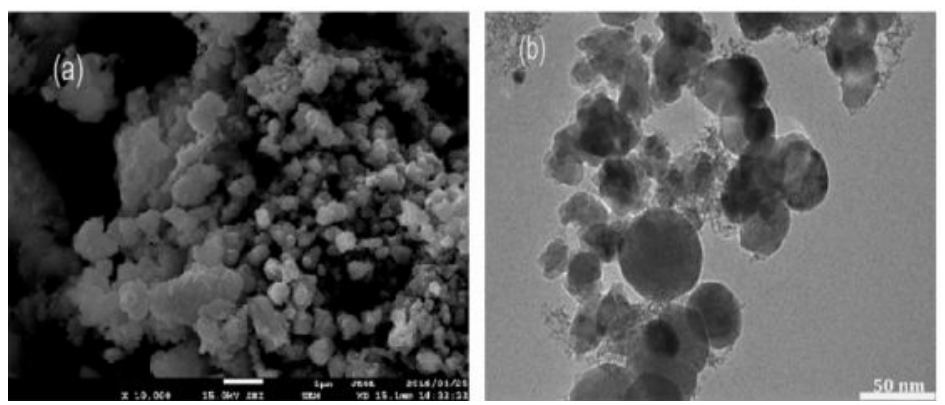

Figure 2. SEM (a) and TEM (b) image of $\mathrm{TiO}_{2}$ nano particles (Yuvarajan et al., 2018)

Nanoparticles have properties that depend on their dimensions. Commonly used methods to characterize dimensions include transmission electron microscopy (TEM), scanning electron microscopy (SEM), atomic force microscopy (AFM), and dynamic light scattering (DLS) (Eaton 
et al., 2017). Figure 2 shows the results of the SEM and TEM characterization of TiO2 nanopartices.

X-ray Diffraction (XRD) is used to confirm that nanoparticles are nano metal oxides. Figure 3 shows the XRD results from $\mathrm{NiO}$ nano particles, where Ni-O particle patterns are found in the range of $20^{\circ}-80^{\circ}$ (Srinidhi et al., 2019).

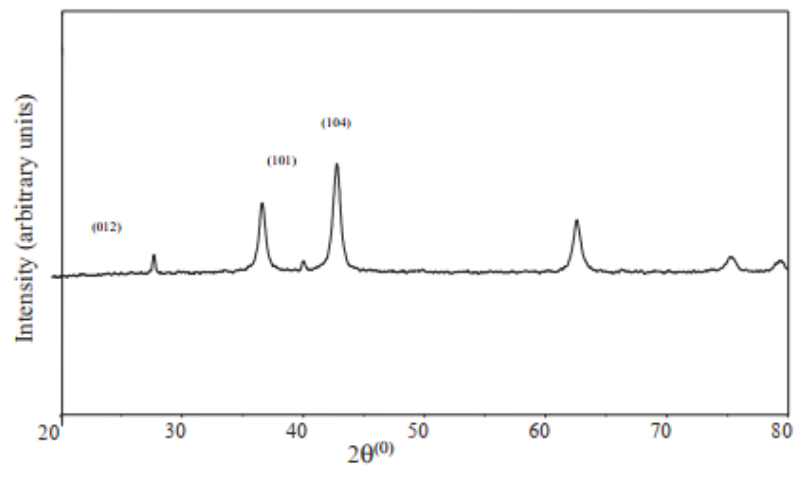

Figure 3. XRD of NiO (Srinidhi et al., 2019)

\subsection{Fuel properties}

The nano metal oxides used as soluble nano additives in biodiesel are 6 to $60 \mathrm{~nm}$ in size with a concentration of 10 to $300 \mathrm{ppm}$. The parameters measured in biodiesel that have been added or not yet added by nano particles are density, viscosity, calorivic value and centane number with ASTM D7467 standard. Various combinations of concentration and particle size that have been used as biodiesel additives in various studies are shown in Table 1.

The higher the concentration of nano particles in biodiesel the higher the density of biodiesel. But in other studies, the density is not so affected by the amount of nano particle concentration in biodiesel (Krupakaran et al., 2016).

Likewise with viscosity. The higher the concentration of nano particles, the higher the viscosity on biodiesel (Anand, 2013) (Mahalingam \& Ganesan, 2018) (Yuvarajan et al., 2017) (Nanthagopal et al., 2017) (Gunasekar et al., 2017). However, other studies state that the higher the concentration of nano particles, the lower the viscosity of biodiesel (Krupakaran et al., 2016) (Nithya et al., 2017) (Karthikeyan \& Prathima, 2016).

Flash points in the study (Anand, 2013) decreased with increasing concentration of nano particles. Whereas other research states that the higher the concentration of nano particles, the flash point is increasing (Krupakaran et al., 2016) (Nanthagopal et al., 2017) (Karthikeyan \& Prathima, 2017a).

At calorific value, the higher the concentration of nano particles, the higher the heat value of biodiesel (Anand, 2013) (Krupakaran et al., 2016). While other studies state that the higher the concentration of nano particles, the lower the heating value of biodiesel. 
Of the ten studies that have been reviewed, the Cetane number has consistency. The higher the concentration of nano particles, the higher the biodiesel cetane number (Anand, 2013) (Krupakaran et al., 2016) (Yuvarajan et al., 2017) (Nithya et al., 2017) (Nanthagopal et al., 2017) (Karthikeyan \& Prathima, 2016) (Gunasekar et al., 2017). From all references reviewed, the addition of nano particles does not significantly affect the density, viscosity, and flash point values, but the cetane number has a relationship with the addition of nano particles. The higher the concentration of nano particles, the higher the value of biodiesel cetane number.

Tabel 1. Summary of fuel properties of biodiesel with soluble additive nano metal oxide

\begin{tabular}{|c|c|c|c|c|c|c|c|c|c|}
\hline Biodiesel & $\begin{array}{l}\text { Nano metal } \\
\text { oxide }\end{array}$ & Size $(\mathrm{nm})$ & $\begin{array}{l}\text { Concentratio } \\
\text { ns (ppm) }\end{array}$ & $\begin{array}{l}\text { Density } \\
\left(\mathrm{kg} / \mathrm{m}^{3}\right)\end{array}$ & $\begin{array}{l}\text { Viscosity } \\
\text { (cSt) }\end{array}$ & $\begin{array}{l}\text { Flash } \\
\text { point } \\
\left({ }^{\circ} \mathrm{C}\right) \\
\end{array}$ & $\begin{array}{c}\text { Calorific } \\
\text { value } \\
(\mathrm{mJ} / \mathrm{kg})\end{array}$ & $\begin{array}{l}\text { Cetane } \\
\text { number }\end{array}$ & Ref. \\
\hline J. Curcas & $\mathrm{Al}_{2} \mathrm{O}_{3}$ & $\begin{array}{c}\text { Rata rata } \\
51\end{array}$ & $\begin{array}{c}0 \\
25 \\
50\end{array}$ & $\begin{array}{l}895 \\
896 \\
897\end{array}$ & $\begin{array}{l}5.25 \\
5.31 \\
5.35\end{array}$ & $\begin{array}{l}85 \\
84 \\
82\end{array}$ & $\begin{array}{l}38.88 \\
39.22 \\
39.53\end{array}$ & $\begin{array}{l}53 \\
54 \\
56\end{array}$ & $\begin{array}{l}\text { (Anand, } \\
\text { 2013) }\end{array}$ \\
\hline $\begin{array}{c}\text { J. Curcas } 20 \% \\
+ \text { Diesel } 70 \%+ \\
\text { Ethanol } 10 \%\end{array}$ & $\mathrm{Al}_{2} \mathrm{O}_{3}$ & & 25 & $\begin{array}{c}837.2 \\
\left(20{ }^{\circ} \mathrm{C}\right)\end{array}$ & 2.57 & 22 & 39.137 & 54 & $\begin{array}{l}\text { (Venu \& } \\
\text { Madhava } \\
\mathrm{n}, 2016)\end{array}$ \\
\hline Palm & $\gamma \mathrm{Al}_{2} \mathrm{O}_{3}$ & $6-12$ & $\begin{array}{c}0 \\
25 \\
50 \\
75 \\
100\end{array}$ & & $\begin{array}{l}4.8 \\
4.76 \\
4.74 \\
4.73 \\
4.73\end{array}$ & $\begin{array}{l}130 \\
160 \\
168 \\
172 \\
180\end{array}$ & $\begin{array}{c}38.49 \\
38.52 \\
38.56 \\
38.582 \\
38.59\end{array}$ & $\begin{array}{l}51 \\
55 \\
59 \\
62 \\
63\end{array}$ & $\begin{array}{l}\text { (Krupaka } \\
\text { ran et al., } \\
2016 \text { ) }\end{array}$ \\
\hline Ruber seed B20 & $\mathrm{Al}_{2} \mathrm{O}_{3}$ & & $\begin{array}{l}10 \\
20 \\
30\end{array}$ & & $\begin{array}{l}4.1 \\
4.2 \\
4.2\end{array}$ & & $\begin{array}{l}42 \\
41 \\
41\end{array}$ & & $\begin{array}{l}\text { (Mahalin } \\
\text { gam \& } \\
\text { Ganesan, } \\
\text { 2018) }\end{array}$ \\
\hline mustard & $\mathrm{TiO}_{2}$ & & $\begin{array}{l}100 \\
200\end{array}$ & & $\begin{array}{l}4.34 \\
4.38\end{array}$ & & $\begin{array}{l}37.854 \\
37.652\end{array}$ & $\begin{array}{l}54 \\
57\end{array}$ & $\begin{array}{l}\text { (Yuvaraj } \\
\text { an et al., } \\
2017 \text { ) }\end{array}$ \\
\hline $\begin{array}{l}\text { C. inophyllum } \\
\text { B20 }\end{array}$ & $\mathrm{TiO}_{2}$ & & 40 & 844.5 & 3.72 & & 41.935 & 53.94 & $\begin{array}{l}\text { (Praveen } \\
\text { et al., } \\
2017 \text { ) }\end{array}$ \\
\hline $\begin{array}{c}\text { Canola } \\
\text { B20 }\end{array}$ & $\mathrm{TiO}_{2}$ & & $\begin{array}{c}0 \\
300\end{array}$ & $\begin{array}{l}915 \\
840\end{array}$ & $\begin{array}{l}4.8 \\
3.4\end{array}$ & & & $\begin{array}{l}42 \\
56\end{array}$ & $\begin{array}{l}\text { (Nithya } \\
\text { et al., } \\
2017)\end{array}$ \\
\hline C. inophyllum & $\mathrm{TiO}_{2}$ & & $\begin{array}{c}0 \\
50 \\
100\end{array}$ & $\begin{array}{l}868.6 \\
869.2 \\
870.4\end{array}$ & $\begin{array}{l}4.72 \\
4.73 \\
4.75\end{array}$ & $\begin{array}{l}122 \\
123 \\
124\end{array}$ & $\begin{array}{c}38 \\
37.12 \\
37.54\end{array}$ & $\begin{array}{l}52 \\
53 \\
55\end{array}$ & $\begin{array}{l}\text { (Nanthag } \\
\text { opal et } \\
\text { al., 2017) }\end{array}$ \\
\hline Algae & $\begin{array}{l}\mathrm{TiO}_{2} \\
\mathrm{SiO}_{2}\end{array}$ & & $\begin{array}{c}0 \\
50 \\
100\end{array}$ & $\begin{array}{c}0.816 \\
(\mathrm{gm} / \mathrm{cc}) \\
817 \\
817\end{array}$ & $\begin{array}{l}3.12 \\
3.03 \\
3.01\end{array}$ & $\begin{array}{l}60.49 \\
62.45 \\
63.61\end{array}$ & $\begin{array}{c}40.422 \\
42.6 \\
44\end{array}$ & $\begin{array}{l}47 \\
48 \\
48\end{array}$ & $\begin{array}{l}\text { (Karthike } \\
\text { yan \& } \\
\text { Prathima, } \\
\text { 2017b) }\end{array}$ \\
\hline C. inophyllum & $\begin{array}{c}\mathrm{TiO}_{2} \\
\mathrm{TiO}_{2}+\text { Ethanox }\end{array}$ & & $\begin{array}{c}0 \\
100 \\
100 \\
200 \\
300\end{array}$ & $\begin{array}{l}815 \\
870 \\
902 \\
904 \\
910\end{array}$ & $\begin{array}{l}3.1 \\
5.1 \\
4.7 \\
4.6 \\
4.8\end{array}$ & & $\begin{array}{c}43 \\
38 \\
38 \\
39 \\
39.2\end{array}$ & $\begin{array}{l}45 \\
52 \\
56 \\
58 \\
59\end{array}$ & $\begin{array}{l}\text { (Gunasek } \\
\text { ar et al., } \\
2017 \text { ) }\end{array}$ \\
\hline C. inophyllum & $\gamma \mathrm{Al}_{2} \mathrm{O}_{3}$ & & $\begin{array}{c}0 \\
100 \\
200 \\
300\end{array}$ & $\begin{array}{l}855.8 \\
864.1 \\
853.5 \\
855.3\end{array}$ & $\begin{array}{c}5.5 \\
5 \\
4.4 \\
3.6\end{array}$ & $\begin{array}{c}101 \\
100 \\
104 \\
97\end{array}$ & $\begin{array}{l}43.10 \\
43.95 \\
43.73 \\
44.25\end{array}$ & & $\begin{array}{l}\text { (Pambud } \\
\text { i et al., } \\
\text { 2021) }\end{array}$ \\
\hline
\end{tabular}

\section{Engine performance}

\subsection{Brake specific fuel consumption (BSFC)}

Brake specific fuel consumption (BSFC) is a complete measurement of fuel consumption in the combustion chamber that shows the vehicle's fuel consumption and power produced in a certain time. BSFC is expressed in units of mass ( $\mathrm{gr} / \mathrm{kWh}$ ). In fact, fuel consumption will be greater in conditions that are not ideal combustion (Mirzajanzadeh et al., 2015). Nano cerium oxides (CeO2) 
particles can reduce brake specific fuel consumption (BSFC) on biodiesel rice bran. Biodiesel 20\% and petrodiesel 80\% (B20), Biodiesel $\mathrm{B} 20+\mathrm{CeO}_{2} 50$ ppm, Biodiesel $\mathrm{B} 20+\mathrm{CeO}_{2} 100$ ppm were tested using 1 cylinder diesel engine test equipment. Biodiesel without the addition of $\mathrm{CeO}_{2}$ nano particles has a higher brake specific fuel consumption (BSFC) value compared to biodiesel with $\mathrm{CeO}_{2}$ nano particles (Karthikeyan et al., 2016). Another research states that the addition of cerium oxide on amide-functionalized multiwall carbon nanotubes (MWCNT) 30, 60, 90ppm to biodiesel of used cooking oil biodiesel 5\% (B5) and biodiesel 20\% (B20) can reduce BSFC by $0.42 \%, 0.84 \%$ and $3.09 \%$ on B5 biodiesel, and $0.34 \%, 1.49 \%$, and $4.51 \%$ in B20 biodiesel.

Nano $\mathrm{CeO}_{2}$ provides oxygen molecules in a chain reaction causing the burning of hydrocarbon and carbon that are not completely burned. Burning more fuel in the cylinder produces more energy. Additionally, $\mathrm{CeO}_{2}$ nano prevents the deposition of non-polar components in the cylinder wall and burns residual carbon. Nano catalysts in fuels produce millions of nano clusters that explode to decompose and to destroy deposits and to prevent the formation of deposits in the cylinder walls (Mirzajanzadeh et al., 2015).

\section{Emission characteristic}

Diesel engines have exhaust gas emission parameters including nitrogen oxide (NOx), carbon monoxide (CO), and hydrocarbons (HC).

\subsection{Nitrogen oxides (NOx)}

Nitrogen oxide is formed due to the presence of nitrogen in the air. Nitrogen reacts with oxygen during the combustion process which affects the amount of NOx content in exhausted gas emissions, among others, combustion temperature, combustion activation energy, and the equivalent ratio in combustion (Mofijur et al., 2013). Biodiesel exhaust gas emissions, containing more NOx compared to petrodiesel due to biodiesel containing oxygen so that the combustion of biodiesel involves more oxygen content and causes the combustion temperature to increase. So that the NOx in the exhaust gas increases (Tüccar et al., 2014).

Metal oxides in biodiesel add local oxygen content in combustion and with the addition of nanoparticles, which increases the duration of diffusion controlled combustion that increases NOx emissions (Aalam et al., 2015) using the additive $\mathrm{Al}_{2} \mathrm{O}_{3}$ biodiesel ziziphus $\mathrm{B} 25$ the higher the concentration of nano particles, the higher the NOx in the flue gas, which is $0 \mathrm{ppm}=3,148 \mathrm{~g}$ / $\mathrm{kWH}, 25 \mathrm{ppm}=3,456 \mathrm{~g} / \mathrm{kWh}$, and 3,729 $\mathrm{g} / \mathrm{kWh}$. However, other studies have revealed that the higher the concentration of nano particles, the lower the NOx concentration (Anand, 2013) $\mathrm{Al}_{2} \mathrm{O}_{3}$ jatropha biodiesel, (Pandian et al., 2017) TiO2 Mahua biodiesel, (Yuvarajan et al., 2018) TiO2 Mustard biodiesel, (Radhakrishnan et al., 2018) $\mathrm{Al}_{2} \mathrm{O}_{3}$ cashew biodiesel. They are of the opinion 
that, however, from the whole NOx biodiesel research with additive nano metal oxide there is still more compared to petrodiesel.

\subsection{Carbon monoxides (CO)}

The formation of $\mathrm{CO}$ emissions is due to the lack of oxygen in combustion, uneven mixing of air and fuel, and lack of combustion processes. From several references that have been reviewed, $\mathrm{CO}$ emissions decrease along with the addition of nano particles to biodiesel or a mixture of biodiesel and petrodiesel. With the addition of $200 \mathrm{ppm} \mathrm{TiO}_{2}$ nano particles to neat mahua biodiesel oil (BD100) can reduce CO emissions by $9.3 \%$ in peak brake power (Pandian et al., 2017). Zizipus jujube biodiesel methyl ester blended fuel (ZJME25) and nano particle $\mathrm{AL}_{2} \mathrm{O}_{3}$ by $25 \mathrm{ppm}$ at full load can reduce CO by 22.66\% (Aalam et al., 2015). Cashew nut sold BD100 biodiesel can reduce $\mathrm{CO}$ emissions by $57.70 \%$ compared to petrodiesel. The addition of $\mathrm{AL}_{2} \mathrm{O}_{3}$ to BD100 biodiesel cashew nut can reduce CO emissions by $62.29 \%$ when compared to petrodiesel and can reduce by $10.85 \%$ when compared to $\mathrm{BD} 100$ biodiesel cashew nut without $\mathrm{AL}_{2} \mathrm{O}_{3}$ (Radhakrishnan et al., 2018).

Nano metal oxide particles as additives on biodiesel can reduce $\mathrm{CO}$ emissions due to the active catalytic effect on metal oxides. The catalytic effect on nano metal oxide increases the rate of mixing of fuel with air during the combustion process, so that the catalyst activity reduces the formation of $\mathrm{CO}$ and converts it to $\mathrm{CO}_{2}$ (Pandian et al., 2017).

\subsection{Hydrocarbon (HC)}

Hydrocarbon (HC) is formed due to incomplete fuel combustion. Along with increasing power in diesel engines hydrocarbon (HC) emissions will also increase because more fuel injection is needed to maintain a constant speed at high power. Insufficient oxygen content in incomplete combustion can result in increased amounts of hydrocarbon (HC) in the flue gas (Annamalai et al., 2016).

The oxygen content in biodiesel contributes to $\mathrm{HC}$ oxidation thereby reducing the $\mathrm{HC}$ content in the flue gas. The addition of nano metal oxide can also increase the oxygen content in biodiesel. Moreover, the addition of $\mathrm{Al}_{2} \mathrm{O}_{3}$ nano metal oxide to zizipus jujube biodiesel methyl ester blended fuel (ZJME25) can reduce $\mathrm{HC}$ emissions by $25 \%$ at $25 \mathrm{ppm}$ and up to $36.11 \%$ at $50 \mathrm{ppm}$ addition compared without using nano metal oxide (Aalam et al., 2015). Cashew nut sold BD100 biodiesel can reduce $\mathrm{HC}$ in exhaust emissions by $20.83 \%$ compared to petrodiesel. And with the addition of nano $\mathrm{A} 12 \mathrm{O} 3$ to biodiesel biodiesel $\mathrm{BD} 100$ can reduce $\mathrm{HC}$ content in exhaust gas by $27.08 \%$ compared to petrodiesel. 


\section{Summary}

This review provides an overview of the development of the use of nano metal oxide as a soluble nano catalyst in biodiesel. The conclusions of the above review are the addition of nano particles does not significantly affect the density, viscosity, and flash point values, but the cetane number has a relationship with the addition of nano particles. It means that the higher the concentration of nano particles, the higher the value of biodiesel cetane number. In other hand, the addition of nano metal oxide can reduce the brake specific fuel consumption (BSFC) of biodiesel because nano metal oxide contains oxygen molecules which can oxidize hydrocarbons and carbon monoxide. More fuel burned causes the energy produced is also greater and decreases fuel consumption. Moreover, the addition of nano metal oxide to biodiesel and its mixture did not significantly influence NOx, but $\mathrm{CO}$ and $\mathrm{HC}$ dropped significantly due to the catalytic effect of nano metal oxide on combustion in the combustion chamber.

\section{References}

Aalam, C. S., Saravanan, C. G., \& Kannan, M. (2015). Experimental investigations on a CRDI system assisted diesel engine fuelled with aluminium oxide nanoparticles blended biodiesel. Alexandria Engineering Journal, 54(3), 351-358. https://doi.org/10.1016/j.aej.2015.04.009

Anand, J. S. B. R. B. (2013). The influence of nano additive blended biodiesel fuels on the working characteristics of a diesel engine. Journal of the Brazilian Society of Mechanical Sciences and Engineering, 257-264. https://doi.org/10.1007/s40430-013-0023-0

Annamalai, M., Dhinesh, B., Nanthagopal, K., SivaramaKrishnan, P., Isaac JoshuaRamesh Lalvani, J., Parthasarathy, M., \& Annamalai, K. (2016). An assessment on performance, combustion and emission behavior of a diesel engine powered by ceria nanoparticle blended emulsified biofuel. Energy Conversion and Management, 123, 372-380. https://doi.org/10.1016/j.enconman.2016.06.062

Ashok, B., Nanthagopal, K., \& Vignesh, D. S. (2017). Calophyllum inophyllum methyl ester biodiesel blend as an alternate fuel for diesel engine applications. Alexandria Engineering Journal. https://doi.org/10.1016/j.aej.2017.03.042

Chauhan, B. S., Kumar, N., \& Cho, H. M. (2011). A study on the performance and emission of a diesel engine fueled with Jatropha biodiesel oil and its blends. Energy, 37(1), 616-622. https://doi.org/10.1016/j.energy.2011.10.043

Demirbas, A. (2005). Biodiesel production from vegetable oils via catalytic and non-catalytic supercritical methanol transesterification methods. Progress in Energy and Combustion Science, 31(5-6), 466-487. https://doi.org/10.1016/j.pecs.2005.09.001

Dhar, A., Kevin, R., \& Kumar, A. (2012). Production of biodiesel from high-FFA neem oil and its performance, emission and combustion characterization in a single cylinder DICI engine. Fuel Processing Technology, 97, 118-129. https://doi.org/10.1016/j.fuproc.2012.01.012

Eaton, P., Quaresma, P., Soares, C., Neves, C., de Almeida, M. P., Pereira, E., \& West, P. (2017). A direct comparison of experimental methods to measure dimensions of synthetic nanoparticles. Ultramicroscopy, 182, 190. https://doi.org/10.1016/j.ultramic.2017.07.001

Energy, U. S. (2017). International Energy Outlook 2016 With Projections to 2040. Retrived from www.eia.gov/forecasts/ieo/pdf/0484(2016).pdf

Fukuda, H., Kondo, A., \& Noda, H. (2001). Biodiesel fuel production by transesterification of oils. Journal of Bioscience and Bioengineering, 92(5), 405-416. https://doi.org/10.1016/S1389- 


\section{3(01)80288-7}

Gong, Z., Wenfei, W., Zhao, Z., \& Li, B. (2018). Combination of catalytic combustion and catalytic denitration on semi-coke with $\mathrm{Fe}_{2} \mathrm{O}_{3}$ and $\mathrm{CeO}_{2}$. Catalysis Today, 318(2010), 59-65. https://doi.org/10.1016/j.cattod.2018.03.073

Gunasekar, P., Manigandan, S., Ilangovan, N., Nithya, S., \& Devipriya, J. (2017). Effect of TiO2 and nozzle geometry on diesel emissions fueled with biodiesel blends. International Journal of Ambient Energy, O(0), 1-19. https://doi.org/10.1080/01430750.2017.1410229

Haberl, H., Beringer, T., Bhattacharya, S. C., Erb, K. H., \& Hoogwijk, M. (2010). The global technical potential of bio-energy in 2050 considering sustainability constraints. Current Opinion in Environmental Sustainability, 2(5-6), 394-403. https://doi.org/10.1016/j.cosust.2010.10.007

Herbinet, O., Pitz, W. J., \& Westbrook, C. K. (2008). Detailed chemical kinetic oxidation mechanism for a biodiesel surrogate. Combustion and Flame, 154, 507-528. https://doi.org/10.1016/j.combustflame.2008.03.003

Hoekman, S. K., \& Robbins, C. (2012). Review of the effects of biodiesel on NOx emissions. Fuel Processing Technology, 96, 237-249. https://doi.org/10.1016/j.fuproc.2011.12.036

How, H. G., Masjuki, H. H., Kalam, M. A., Teoh, Y. H., \& Chuah, H. G. (2018). Effect of Calophyllum Inophyllum biodiesel-diesel blends on combustion, performance, exhaust particulate matter and gaseous emissions in a multi- cylinder diesel engine. Fuel, 227(October 2017), 154-164. https://doi.org/10.1016/j.fuel.2018.04.075

Karthikeyan, S., Elango, A., \& Prathima, A. (2016). The effect of cerium oxide additive on the performance and emission characteristics of a CI engine operated with rice bran biodiesel and its blends. International Journal of Green Energy, 13(3), 267-273. https://doi.org/10.1080/15435075.2014.952419

Karthikeyan, S., \& Prathima, A. (2016). Environmental Effects Environmental effect of $\mathrm{CeO}_{2}$ nanoadditive on biodiesel. 7036. https://doi.org/10.1080/15567036.2016.1177624

Karthikeyan, S., \& Prathima, A. (2017a). Environmental effect of CI engine using microalgae methyl ester with doped nano additives. Transportation Research Part D, 50, 385-396. https://doi.org/10.1016/j.trd.2016.11.028

Karthikeyan, S., \& Prathima, A. (2017b). Microalgae biofuel with $\mathrm{CeO}_{2}$ nano additives as an ecofriendly fuel for CI engine. Energy Sources, Part A: Recovery, Utilization and Environmental Effects, 39(13), 1332-1338. https://doi.org/10.1080/15567036.2017.1328002

Krupakaran, R. L., Hariprasasd, T., Gopalakrishna, A., \& Babu, P. (2016). The performance and exhaust emissions investigation of a diesel engine using $\gamma-\mathrm{Al}_{2} \mathrm{O}_{3}$ nanoparticle additives to biodiesel. Carbon Management, 7(3-4), 233-241. https://doi.org/10.1080/17583004.2016.1218713

Mahalingam, S., \& Ganesan, S. (2018). Effect of nano-fuel additive on performance and emission characteristics of the diesel engine using biodiesel blends with diesel fuel. International Journal of Ambient Energy, O(0), 1-6. https://doi.org/10.1080/01430750.2018.1437566

Mirzajanzadeh, M., Tabatabaei, M., Ardjmand, M., \& Rashidi, A. (2015). A novel soluble nanocatalysts in diesel - biodiesel fuel blends to improve diesel engines performance and reduce exhaust emissions. FUEL, 139(x), 374-382. https://doi.org/10.1016/j.fuel.2014.09.008

Mofijur, M., Masjuki, H. H., Kalam, M. A., \& Atabani, A. E. (2013). Evaluation of biodiesel blending, engine performance and emissions characteristics of Jatropha curcas methyl ester: Malaysian perspective. Energy, 55, 879-887. https://doi.org/10.1016/j.energy.2013.02.059

Najafi, G. (2018). Diesel engine combustion characteristics using nano-particles in biodieseldiesel blends. Fuel, 212(January), 668-678. https://doi.org/10.1016/j.fuel.2017.10.001

Nanthagopal, K., Ashok, B., Tamilarasu, A., Johny, A., \& Mohan, A. (2017). Influence on the effect of zinc oxide and titanium dioxide nanoparticles as an additive with Calophyllum inophyllum methyl ester in a CI engine. Energy Conversion and Management, 146, 8-19. https://doi.org/10.1016/j.enconman.2017.05.021

Nithya, S., Manigandan, S., Gunasekar, P., Devipriya, J., \& Saravanan, W. S. R. (2017). The Effect 
of engine emission on canola biodiesel blends with $\mathrm{TiO}_{2}$. International Journal of Ambient Energy. 0750. https://doi.org/10.1080/01430750.2017.1421583

Özener, O., Yüksek, L., Ergenç, A. T., \& Özkan, M. (2014). Effects of soybean biodiesel on a DI diesel engine performance, emission and combustion characteristics. Fuel, 115(10), 875-883. https://doi.org/10.1016/j.fuel.2012.10.081

Pambudi, S., Ilminnafik, N., Junus, S., \& Kustanto, M. N. (2021). Experimental study on the effect of nano additives $\gamma \mathrm{Al}_{2} \mathrm{O}_{3}$ and equivalence ratio to Bunsen flame characteristic of biodiesel from nyamplung (Calophyllum Inophyllum). Automotive Experiences, 4(2), 51-61. https://doi.org/10.31603/ae.4569

Pandian, A. K., Ramakrishnan, R. B. B., \& Devarajan, Y. (2017). Emission analysis on the effect of nanoparticles on neat biodiesel in unmodified diesel engine. Environmental Science and Pollution Research, 24(29), 23273-23278. https://doi.org/10.1007/s11356-017-9973-6

Praveen, A., Rao, G. L. N., \& Balakrishna, B. (2017). Performance and emission characteristics of a diesel engine using Calophyllum Inophyllum biodiesel blends with $\mathrm{TiO} 2$ nanoadditives and EGR. Egyptian Journal of Petroleum. https://doi.org/10.1016/j.ejpe.2017.10.008

Puzyn, T., Rasulev, B., Gajewicz, A., Hu, X., Dasari, T. P., Michalkova, A., Hwang, H. M., Toropov, A., Leszczynska, D., \& Leszczynski, J. (2011). Using nano-QSAR to predict the cytotoxicity of metal oxide nanoparticles. Nature Nanotechnology, 6(3), 175-178. https://doi.org/10.1038/nnano.2011.10

Radhakrishnan, S., Munuswamy, D. B., Devarajan, Y., Arunkumar, T., \& Mahalingam, A. (2018). Effect of nanoparticle on emission and performance characteristics of a diesel engine fueled with cashew nut shell biodiesel. Energy Sources, Part A: Recovery, Utilization and Environmental Effects, 40(20), 2485-2493. https://doi.org/10.1080/15567036.2018.1502848

Raheman, H., \& Ghadge, S. V. (2007). Performance of compression ignition engine with mahua (Madhuca indica) biodiesel. Fuel. 86, 2568-2573. https://doi.org/10.1016/j.fuel.2007.02.019

Rahman, S. M. A., Masjuki, H. H., Kalam, M. A., Abedin, M. J., Sanjid, A., \& Sajjad, H. (2013). Production of palm and Calophyllum inophyllum based biodiesel and investigation of blend performance and exhaust emission in an unmodified diesel engine at high idling conditions. Energy Conversion and Management, 36, 362-367. https://doi.org/10.1016/j.enconman.2013.07.061

Srinidhi, P. C., Madhusudhan, A., \& Channapattana, S. V. (2019). Effect of NiO nanoparticles on performance and emission characteristics at various injection timings using biodiesel-diesel blends. Fuel, 235(March 2018), 185-193. https://doi.org/10.1016/j.fuel.2018.07.067

Tüccar, G., Tosun, E., Özgür, T., \& Aydin, K. (2014). Diesel engine emissions and performance from blends of citrus sinensis biodiesel and diesel fuel. Fuel, 132, 7-11. https://doi.org/10.1016/j.fuel.2014.04.065

Van Gerpen, J. (2005). Biodiesel processing and production. Fuel Processing Technology, 86(10), 1097-1107. https://doi.org/10.1016/j.fuproc.2004.11.005

Varatharajan, K., \& Cheralathan, M. (2012). Influence of fuel properties and composition on NO $\mathrm{x}$ emissions from biodiesel powered diesel engines: A review. Renewable and Sustainable Energy Reviews, 16(6), 3702-3710. https://doi.org/10.1016/j.rser.2012.03.056

Venu, H., \& Madhavan, V. (2016). Effect of $\mathrm{Al}_{2} \mathrm{O}_{3}$ nanoparticles in biodiesel-diesel-ethanol blends at various injection strategies: Performance, combustion and emission characteristics. Fuel, 186, 176-189. https://doi.org/10.1016/j.fuel.2016.08.046

Wang, Y., Zhou, Z., Yang, W., Zhou, J., Liu, J., Wang, Z., \& Cen, K. (2010). Combustion of hydrogen-air in micro combustors with catalytic Pt layer. Energy Conversion and Management, 51(6), 1127-1133. https://doi.org/10.1016/j.enconman.2009.12.021

Wickham, D. T., Cook, R., Voss, S. De, Engel, J. R., \& Nabity, J. (2006). Soluble nano-catalysts for high performance fuels. Journal of Russian Laser Research. 27(6), 552-561.

Wierzbicki, T. A., Lee, I. C., \& Gupta, A. K. (2014). Combustion of propane with Pt and Rh catalysts in a meso-scale heat recirculating combustor. APPLIED ENERGY, 130, 350-356. https://doi.org/10.1016/j.apenergy.2014.05.069 
Yuvarajan, D., Dinesh Babu, M., BeemKumar, N., \& Amith Kishore, P. (2018). Experimental investigation on the influence of titanium dioxide nanofluid on emission pattern of biodiesel in a diesel engine. Atmospheric Pollution Research, 9(1), 47-52. https://doi.org/10.1016/j.apr.2017.06.003 